\title{
Left Ventricular Systolic Dysfunction
}

National Cancer Institute

\section{Source}

National Cancer Institute. Left Ventricular Systolic Dysfunction. NCI Thesaurus. Code C64251.

The degree of impairment of the left cardiac ventricle to contract efficiently. (ACC) 